\title{
Determinants of Potato Marketed Surplus among Smallholder Farmers in Sekela District, West Gojjam Zone of Amhara Region, Ethiopia
}

\author{
Yaregal Tilahun Geremewe* \\ Department of Agricultural Economics and Natural Resource, Mizan Tepi University, Mizan Tepi, Ethiopia \\ *Corresponding Author: Yaregal Tilahun Geremewe, Department of Agricultural Economics and \\ Natural Resource, MizanTepi University, Mizan Tepi, Ethiopia
}

\begin{abstract}
For Sekela Woreda smallholder potato producers, potato has significant contribution for consumption at home which increase food security and in generating cash income. Therefore, enhancing potato producers' access to market and linking them to most beneficial outlets is a key issue needed in the study area. This paper was aimed to identify factors affecting marketed surplus potato farmers using survey data collected from randomly selected 130 farmers from six kebeles were randomly and proportionately sampled to collect both secondary and primary sources. Descriptive statistics was used for characterizing farmers and econometrics analysis was used for identifying determinants of marketed surplus. The result of econometric analysis from OLS marketed surplus model revealed that distance to the nearest market, use of improved seed, frequency of extension contact, area of land allocated for potato and yield of potato significantly determined quantity of potato supplied to the market. Based on the finding the government and other stakeholders need to focus on strengthening improved seed access, strengthening rural-urban infrastructure, expanding market access, improving land management practices and yield through strengthening extension service in order to accelerate market chain development.
\end{abstract}

Keywords: Marketed surplus, Potato, Multiple linear regression

\section{INTRODUCTION}

Potato (Solanum tuberosum L.) popularly known as 'The king of vegetables', which is the fourth most important food crop after maize, wheat and rice worldwide (Naz et al., 2011). It has been considered as a strategic crop by the Ethiopian government aiming at enhancing food security and economic benefits to the country. The percentage of potato consumed at home at country level is more than that of cereals and pulses and at least for once the consumers can eat potato. The reason for huge consumption level of the crop is due to increasing in the demand of the consumer, increase population growth, growth in fast food restaurants and a rise in the price of cereal products (Gildemacher et al., 2009). According to CSA (2012) report about 79\%, $18 \%$ and nearly $1 \%$ of the vegetables produced were used for household consumption, sale and seed respectively. The proportion for potato used for consumption, sale and seed were $64 \%, 20 \%$ and $14 \%$ respectively.

Potato is regarded as a high potential to food security due to its potential source of cash income for low-income farmers, provide high yield of high-quality product per unit input with a shorter crop cycle (mostly less than 120 days) than major cereal crops (Ephrem, 2015). It is a carbohydrate-rich, high source of vitamin C, vitamins B1, B2 and B6 and minerals such as potassium, phosphorous and magnesium and energy-providing food with little fat. Its average composition contains about $80 \%$ water, $2 \%$ protein and $18 \%$ starch (Haverkort et al., 2012).

The development of potato production and marketing in Ethiopia are characterized by seasonal surpluses and shortages in the off season which in turn affect the marketing behavior of producers, traders and consumers due to a number of factors: inadequate vegetable seed regulatory frameworks, limited public institutional capacity and capability supporting efficient and regular vegetable seed supply, high post-harvest losses, high incidence of diseases and insect pests, poor vegetable marketing, weak linkage and integration among stakeholders, lack of coordination among producers to increase their bargaining power and lack of transparency in market information system (Bezabih et al., 2014) 
An efficient, integrated, and responsive market mechanism is a critical importance for solving those marketing problems through optimal allocation of resources in agricultural production in order to stimulate farmers output and income (Jema, 2008). So, in order to maximize the income that they may earn, farmers have to make appropriate decisions as to where and when they should sell their product. However, there are various factors that affect households' decision to supply their product to the market. Identifying these factors is very important in terms of pinpointing possible interventions that may help farmers to maximize their benefits and to increase their income in potato production and marketing activities (Bezabih et al., 2015).

\section{RESEARCH METHODOLOGY}

\subsection{Description of the Study Area}

Sekela is one of the fifteen Woredas in West Gojjam Zone of Amhara National Regional State. It is located at $459 \mathrm{Kms}$ in North West of Addis Ababa, the capital of Ethiopia; it is $160 \mathrm{Kms}$ in South East of Bahir Dar, the capital of Amhara National Regional State, and $74 \mathrm{Kms}$ in North East of Finote Selam, the capital town of West Gojjam Zone. It is bordered on Southwest by Bure Woreda, on the West by Agew Awi Zone, on the North by Mecha Woreda, on the East by Quarit Woreda and on the South East by Jabi Tehnan. The administrative center of Sekela Woreda is Gish Abay town. The district has a total of 27 kebeles of which 26 are rural based kebeles and only 1 is urban kebeles (SWAO, 2017).

According to SWHO (2017), the total population of the district was 162,204 of which male accounts for $79,071(48.7 \%$ ) and female accounts $83,133(51.3 \%)$ of the total population. Besides from $48.7 \%$ of male population of the district, $92.65 \%$ of them are living in rural areas and the remaining $7.35 \%$ are urban residents. In addition to that, from the $51.3 \%$ female populations of the district, $91.35 \%$ of them are living in the rural areas and the other $8.65 \%$ are urban dwellers. The estimated total area coverage of the district is 6534.5 hectares. It is located at an elevation of 3062 meter above sea level and $10^{\circ} 55^{\prime} 0^{\prime \prime}$ $\mathrm{N}$ latitude and $37^{\circ} 31^{\prime} 60^{\prime \prime} \mathrm{E}$ longitude. The average annual rainfall of the area ranges from $1600 \mathrm{~mm}$ to $1800 \mathrm{~mm}$ with an average temperature of $18^{\circ} \mathrm{C}$. The district is characterized by $70 \%$ highland (Dega), $18 \%$ midland (Woynadega) and $12 \%$ lowland (Qola) agro-ecological zones (SWAO, 2017).

According to SWAO (2017), almost all the populations of the district are Amhara ethnic groups and 99.94\% of them are Amharic language speakers and $99.96 \%$ of the populations in study area are followers of Orthodox Christianity religion and the remaining $0.04 \%$ of them is other religion followers. The economic base of the population is depend on crop production and animal fattening. About $98 \%$ of the populations are involved in agricultural activities and the remaining $2 \%$ are participant in other off-farming economic activities such as trade, and local alcohol distilling. Agricultural activities are highly dependent on Kiremt (summer) which falls from June to September. The main crops cultivated in the district are potato, barley, gebto and bean. In which potato produced mainly for both household consumption and marketing (SWAO, 2017).

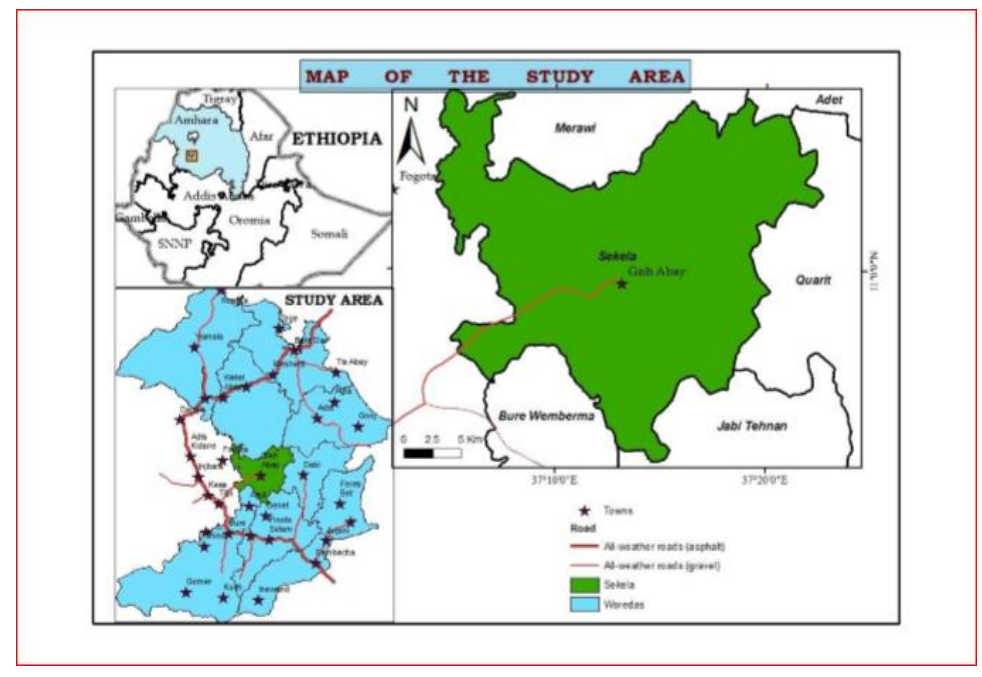

Figure1. Location of the study area

Sources: Ethio - GIS 


\subsection{Data Types and Methods of Data Collection}

Both primary and secondary data were used through formal survey for this study. The formal survey was undertaken through interviews with selected potato producer farmers using a pre-tested structured and semi-structured questionnaire. Secondary data was collected from published and unpublished documents, and internet sources.

\subsection{Sampling Techniques and Sample Size}

The study area, Sekela district was selected as a study area since the area has high potential for potato production and marketing. For sampling producers, two-stage sampling technique was implemented. The district has 26 rural kebeles; on which all of them produce potato. At the first stage, from a total of 26 kebeles of the district, 4 potato producing kebeles were selected randomly. In the second stage, from the selected Kebles about 130 sample households were selected randomly using probability proportionate size. There is no common consensus formula that yields optimal sample size to run a regression model and the controversy is still unsettled. So, scholars have failed to reach common consensus, which leads various researchers to use different methods to determine sample size. Due to this, most statisticians and econometricians' use rule of thumb by consider independent variables to determine sample size. By using rule of thumb $\mathrm{n} \geq 10$ times the number of relevant independent variables in a given model $n=10 \mathrm{~K}$. Where, $\mathrm{K}$ is the number of independent variables included in the model. This indicated that for one independent variable 10 observations was reported optimal.

Table1. Distribution of sample households in the district.

\begin{tabular}{|c|c|c|}
\hline Name of Kebles & Total number of households & Proportion of Households \\
\hline Lichma & 716 & 23 \\
\hline Rebu Gebeya & 778 & 25 \\
\hline Gumbela & 1152 & 37 \\
\hline Abay Sangeb & 1401 & 45 \\
\hline Total & 4047 & 130 \\
\hline
\end{tabular}

Source: Woreda Health Office own computation, 2012

\subsection{Methods of Data Analysis and Model Specification}

Descriptive statistics and econometric analysis were used to analyze the data collected from potato producers. Descriptive statistics employed frequency, percentages and mean in the process of describing households' characteristics. Econometric analysis was used for multiple linear regression model. Since different researchers like (Kindie, 2007, Yimer, 2015 and Hiwot, 2016) used multiple linear regression model to analyze factors affecting marketable supply, this study also used multiple linear regression model to identify factors affecting marketable supply of potato to the market.

Gujarati (2003) the multiple linear regression models are specified as $\mathrm{Y}=\mathrm{f}$ (distance to nearest market, sex of the household head, yield, frequency of extension contact, area of land allocated for potato production, education level of household head, amount of credit taken, family size, experience of potato production, ownership of transport facility, off/non-farm income and use of improved seed ). Potato marketed surplus is a continuous dependent variable which is measured in quintal and represents the actual supply of potato by farm households to the market in the year 2016/17. The econometric model specification of supply function in matrix notation is estimated by

$\mathrm{Y}=\beta_{\mathrm{i}} \mathrm{X}_{\mathrm{i}}+\mathrm{U}_{\mathrm{i}}$

Where $Y_{i}=$ fruit supplied to the market, $\beta=$ a vector of estimated coefficient of the explanatory variables. $\mathrm{X}=\mathrm{a}$ vector of explanatory variables and $\mathrm{U}_{\mathrm{i}}=$ disturbance term

Table2. Summary of independent variables used in the multiple linear regression model.

\begin{tabular}{|c|c|c|c|}
\hline Variable name & Types & Measurement & Hypotheses \\
\hline Quantity supply & Continuous & Quintal & +ve \\
\hline Yield & Continuous & Qt/ha & -ve \\
\hline Family size & Continuous & Adult equivalent & +ve \\
\hline Ownership of transport facility & Dummy & 1 Yes, 0 No & $+\mathrm{ve}$ \\
\hline Land allocated for potato production & Continuous & Hectare & $+\mathrm{ve}$ \\
\hline
\end{tabular}


Determinants of Potato Marketed Surplus among Smallholder Farmers in Sekela District, West Gojjam Zone of Amhara Region, Ethiopia

\begin{tabular}{|c|c|c|c|}
\hline Distance to nearest market & Continuous & walking minutes & -ve \\
\hline Sex of households head & Dummy & 1 Male, 0 No & +ve/-ve \\
\hline Education level of households head & Continuous & Year & $+\mathrm{ve}$ \\
\hline Access to improved seed & Dummy & $1 \mathrm{Yes}, 0 \mathrm{No}$ & $+\mathrm{ve}$ \\
\hline Income from off/nonfarm income & Continuous & Birr & $+\mathrm{ve} /$-ve \\
\hline Frequency of extension contact & Continuous & Number & $+\mathrm{ve}$ \\
\hline Amount of credit taken & Continuous & birr & $+\mathrm{ve}$ \\
\hline Experience for potato production & Continuous & Year & $+\mathrm{ve}$ \\
\hline
\end{tabular}

\section{RESUlT AND DiSCUSSION}

\subsection{Factors Affecting Potato Marketed Surplus}

In the study area potato is an important crop used as source of cash income and for household food consumption. Out of total volume produced in the year, $51.6 \%$ of potato was supplied to the market, about $33.6 \%$ of the output was used as consumption and $14.8 \%$ was kept as seed for the next production season.

For this study 12 explanatory variables were hypothesized as factors affecting household level marketed surplus of potato. The hypothesized variables were sex, family size, education level of the household head, distance to nearest market,0wnership of transportation facility, use of improved seed, size of land allocated for potato, yield, off/non-farm income, frequency of extension contact and amount of credit taken. From these, five variables are found to be significantly affecting marketed surplus of potato. Distance to the nearest market, use of improved seed, size of land allocated for potato; yield and frequency of extension contact influenced the marketed surplus of potato. The F-test calculated value $\mathrm{F}(12,117)=54.64$ was significant; and the adjusted $\mathrm{R}^{2}$ was computed to be 83.31 implying that $83.31 \%$ of the variation in the dependent variable was explained by the explanatory variables under consideration.

Table3. Determinants of marketed surplus of potato.

\begin{tabular}{|c|c|c|c|}
\hline Variables & Coefficients & Standard errors & t value \\
\hline Sex & 1.124 & 1.959 & 0.57 \\
\hline Family size (Adult equivalent) & -0.037 & 0.350 & -0.11 \\
\hline Level of education & -0.386 & 0.284 & -1.36 \\
\hline Experience of potato production & 0.015 & 0.066 & 0.23 \\
\hline Distance to nearest market & $-0.056^{* * *}$ & 0.013 & -4.16 \\
\hline Ownership of transportation & -0.857 & 1.301 & -0.66 \\
\hline Use of improved seed & $1.115^{* *}$ & 0.525 & 2.12 \\
\hline Size of land allocated for potato & $9.911^{* * *}$ & 0.713 & 13.90 \\
\hline Yield & $0.517^{* * *}$ & 0.109 & 1.33 \\
\hline Off/non-farm income $(\log )$ & 0.179 & 0.135 & -0.92 \\
\hline Frequency of extension contact & $0.809^{* *}$ & 0.390 & -1.91 \\
\hline Amount of credit taken $(\log )$ & -0.126 & 0.137 & \\
\hline Constant & $-7.680^{*}$ & 4.018 & \\
\hline Number of observations & 130 & & \\
F (12, 117) & 54.64 & & \\
Prob $>$ F & $0.0000^{* * *}$ & & \\
R-squared & 0.8486 & & \\
Adjusted R-square & 0.8331 & & \\
\hline Durbin Wu-Hausman test $\left(\mathrm{X}^{2}\right)$ & $0.3007(\mathrm{P}=0.31)$ & & \\
\hline
\end{tabular}

$* * *, * *$ and $*$ significant at $1 \%, 5 \%$ and $10 \%$ probability level respectively.

Source: Own survey results, 2017

Before the interpretation of model coefficients, better to test some the assumption of CLR model should hold true. Hence, multicolliniarity, heteroscedasticity and model specification error test (test for omitted variables) were performed using appropriate statistical tests. VIF was employed to test the existence of muliticollineratity among explanatory variables and the result showed that the mean VIF was 1.68 which indicates no problem of multicolliniarity among explanatory variables in the model. Breusch Pagan/Cook-Weisberg test for heteroscedasticity was used and the result indicated that 
heteroscedasticity was not a problem. Furthermore, regression specification error test, test of omitted variables result showed that no omitted variables in the model. Testing for endogeneity of yield of potato were carried out in the model using both Hausman test and Durbin-Wu-Hausman (DWH) test and endogeneity problem were not found in yield of potato.

Distance to the Nearest Market: It affected the quantity of potato supplied to market negatively and significantly at $1 \%$ significance level. The model result indicated that other explanatory variables being constant, as the distance of the producers' residence from the nearest market increase by one walking minute, the quantity of potato supplied decrease by 0.056 quintal. Since potato is highly perishable and bulky product, producers reside far from the nearest market increase marketing cost because there is no transportation, road and market access in the district while those producers near to the market can easily supply without incurring substantial cost. So, due to increase in transportation cost producers discourage selling high quantity of potato output to market. Yimer (2015), me brat (2014) and Abraham (2013) found that distance to nearest market caused marketed surplus of fruit, tomato and cabbage to decline.

Access of Improved Seed: As hypothesized, it influenced the quantity of potato supplied to market positively and significantly at 5\% significance level. The positive sign shows being a household who used improved seed can increase quantity of potato supplied to market by 1.12 quintal as compared to that of non-use households, keeping other variables constant. Farmers using improved seeds often capture higher potato yields and thus are more likely to increase outputs and market surplus and producers would benefit from planting them. Uses of improved seeds are the most important input that promote production and yield and increase farm income (Goitom, 2009). Hence, the more they use for improved seed, the more they produce and the more they tend to supply to the market. The result of this study goes along with the findings of Kumilachew (2016) and Emmanuel et al. (2016) that when producers used improved seed the supply of potato to the market becomes increase. However, delivery of improved potato seeds at a right time is still a major challenge to a number of smallholder producers in the study area.

Size of Land Allocated for Potato: The result shows that land allocated for potato has positive and significant effect on quantity of potato sold at $1 \%$ significant level. The positive sign of the coefficient implies that the larger the land size allocated for potato production, the larger the quantity produce and increase in the supply of potato to market. Increase in the size of land allocated for potato by one hectare leads an increase volume sale of potato by 9.91 quintal, keeping other factors constant. Melkamu et al. (2017) and Addisu (2016) indicated that the area of land allocated for potato production affected farm level marketed supply of potato significantly and positively.

Yield: The result shows that potato yield was positively and significantly related with quantity of potato supplied to market at $1 \%$ significance level. The positive and significant relationships between the two variables indicate that potato yield (output per unit of land) is very important variable affecting the volume of potato market supply. The coefficient for yield implies that an increase in yield of potato by one quintal per hectare resulted in an increase in farm level market supply of potato by 0.52 quintal, keeping other factors constant. Addisu (2016); Bosena (2008) and Rehima (2006) showed that the yield of potato, cotton and red pepper produced by households significantly and positively affected the market supply of each commodity respectively.

Frequency of Extension Contact: As it was hypothesized, result of the finding indicated that frequency of extension contact was positively and significantly related to the quantity of potato supplied to market at 5\% significance level. From the result as other explanatory variables being constant, an increase in frequency of extension contact by one day per month resulted in an increase in farm level market supply of potato by 0.8 quintal. This suggests that extension contact avails information regarding to the use of fertilizers, seedling raising and harvesting time that would improve their production and market supply. Yimer (2015) and Ayelech (2011) showed that as the number of farmer contact to the extension service can affect the market supply of fruits significantly and positively. 


\section{CONCLUSION AND RECOMMENDATION}

\subsection{Conclusion}

This study was aimed to identify the determinants of potato marketed surplus among small holder farmers. The data were collected from both primary and secondary sources. The primary data were collected from individual interview using structured and semi-structured questionnaire from 130 randomly selected potato producer households. Secondary data were obtained from different sources like published and unpublished documents and internet sources.

Econometric result of multiple linear regression (MLR) model indicated that use of improved seed, distance to the nearest market, frequency of extension contact, size of land allocated for potato production and yield were significantly determined the quantity of potato supplied to market. However, from those mentioned significant variables, only distance to the nearest market was significantly and negatively affected the market supply of potato.

\subsection{Recommendation}

From the findings of this study the following recommendation are drown: To start with, even though potato is significant contributor in food security and source of cash income for study area potato producers, producers in the study area are small-scale and unorganized. So, it need government intervention through development of farmers' cooperatives as well as developing linkage among market chain actors to improve production and access to information. Application of recommended chemical fertilizer rate, controlling disease and pest outbreak, development of improved varieties and improve credit access in the district should be promoted by extension service to increase both in production and market supply of potato.

Secondly, market supply of potato was significantly and negatively affected by distance to market place. As the producers reside far from the nearest market, this discourages for selling large quantity of their product due to lack of transportation and road facility. So due to long distance for the woreda market and lack of market access in the district, special attention need to be given to expand accessibility of infrastructures such as road, transportation facilities and rural market accessibility to promote production and marketing of potato.

Thirdly, the volume of potato marketed is positively and significantly affected by the use of improved seed. Even if there is no adequate provision of improved seed in the district, producers who used the input can produce more and can supply more to market. Therefore, dissemination and provision of required amount of improved seed /disease resistant varieties at a right time with a right quality and quantity to all producers need to be given more emphasis.

Fourthly, both the area allocated for potato production and yield affected the market supply of potato positively and significantly. However, increasing landholding size cannot be an option to increase potato market supply since supply of land is limited by nature. Hence, increasing yield of potato per unit area of land is better alternative to increase marketed surplus of potato through relying intensive cultivation, introducing improved varieties, application of chemical fertilizers and controlling disease and pest practice at a right time with a right quantity.

Fifthly, frequency of extension contact affected market supply of potato significantly and positively since it avails information regarding technology like proper methods of pre-harvest production and post- harvest handling technique, seed bed preparation, marketing and fertilizer application which improve production that affect the market supply. Hence, it is necessary to strengthen extension service in order to give continuous training and information to potato producers, to provide necessary agricultural inputs at a right time to improve production and marketing system.

\section{REFERENCES}

[1] Abraham Tegegne. 2013. Value chain analysis of vegetables: The case of Habro and Kombolcha Woredas in Oromia Region, Ethiopia. MSc Thesis, Haramaya University, Haramaya, Ethiopia.

[2] Addisu Hailu. 2016. Value chain analysis of vegetables: the case of Ejere Woreda, in ONRS of Ethiopia. MScThesis, Haramaya University, Haramaya, Ethiopia.

[3] Ayelech Tadesse. 2011. Market chain analysis of fruits for Gomma Woreda, Jimma zone, Oromia National Regional State. MSc Thesis, Haramaya University, Haramaya, Ethiopia. 
[4] Bezabih Emana, Amsalu Ayana, Tesfaye Balemi and Milkessa Temesgen. 2014. Scoping Study on Vegetables Seed Systems and Policy in Ethiopia. Addis Ababa, Ethiopia.

[5] Bezabih Emana, Mengistu Ketema, Jeffreyson, K. Mutimba and Jemal Yousuf. 2015. Factors Affecting Market Outlet Choice of Potato Producers in Eastern Hararghe Zone, Ethiopia. Journal of Economics and Sustainable Development. 6(15):159-172.

[6] CSA (Central Statistical Agency). 2012. Agriculture Sample Survey 2011/2012 (2003 E.C). Report on Area and Production of Major Crops (Private Peasant holdings, Meher seasons). Addis Ababa Ethiopia, The FDRE statistical bulletin Volume 07-532.

[7] Emmanuel, T., Kobayashi, H., Ichizen, M., Esham, M. and Balde, S. B. 2016. Potato Production and Supply by Smallholder Farmers in Guinea: An Economic Analysis. Asian Journal of Agricultural Extension, Economics \& Sociology, 8(3): 1-16.

[8] Ephrem Guchi. 2015. Disease management practice on potato (Solanumtuberosum L.) in Ethiopia. World Journal of Agricultural Research, 3(1): 34-42.

[9] Gildemacher, P. R, Kaguongo, W., Ortiz, O., Tesfaye Agajie, Woldegiorgis, Woldegiorgis, Wagoire, W. W, Kakuhenzire, R., Kinyae, P. M, Nyongesa, M. and Struik P. C. 2009. Improving Potato Production in Kenya, Uganda and Ethiopia: A System Diagnosis. Potato Research, 52: 173-205.

[10] Haverkort, A.J., Koesveld, M.J., van Schepers, H.T., Wijnands, J.M., Wustman, R. and Zhang, X.Y. 2012. Potato Prospects for Ethiopia: On the Road to Value Addition. Lelystad: PPO-AGV. The Netherlands, 528: 1-66.

[11] Hiwot Getahun. 2016. Market chain analysis of groundnut: The case of Gursum District, Oromia National Regional State, Ethiopia. MSc Thesis, Haramaya University, Haramaya, Ethiopia.

[12] Jema Haji. 2008. Economic efficiency and marketing performance of vegetable production in the Eastern and Central Parts of Ethiopia. A PhD Thesis submitted to SLU, Sweden.

[13] Kinde Aysheshm. 2007. Sesame market chain analysis: the case of Metema Woreda, North Gondar zone, Amhara National Regional State (published MSc thesis). MSc thesis, Haramaya University, Haramaya, Ethiopia.

[14] Mebrat Tola. 2014. Tomato Value Chain Analysis in the Central Rift Valley: The Case of Dugda Woreda, East Shoa Zone, Oromia National Regional State. MSc Thesis, Haramaya University, Haramaya, Ethiopia

[15] Melkamu Bazie, Degye Goshu, Bosena Tegegne. 2017. Determinants of Potato Marketed Surplus among Smallholder Farmers in Banja District, Awi Zone of Amhara Region, Ethiopia. International Journal of Agricultural Economics, 2(4); 129-134

[16] Naz, F., Ali, A., Iqbal Z., Akhtrr N., Asghar S. and Ahmad. 2011. Effect of NPK fertilizers on proximate composition of potato crop at Abbott bad. Sarhad Journal of Agriculture, 27 (3): 353 - 356.

[17] Rehima Musema. 2006. Analysis of Red Pepper Marketing: The Case of Alaba and Siltie in SNNPRS of Ethiopia. MSc Thesis, Haramaya University, Haramaya, Ethiopia.

[18] Yimer Ayalew. 2015. Factors Affecting Fruit Supply in the Market: The case of Habru Woreda, North Wollo, Ethiopia Regional State, Ethiopia. Journal of Marketing and Consumer Research, 7:40.

Citation: Yaregal Tilahun Geremewe, (2019). "Determinants of Potato Marketed Surplus among Smallholder Farmers in Sekela District, West Gojjam Zone of Amhara Region, Ethiopia” International Journal of Research Studies in Agricultural Sciences (IJRSAS), 5(1), pp.20-26, http://dx.doi.org/10.20431/ 2454-6224.0501004

Copyright: (C) 2019 Authors. This is an open-access article distributed under the terms of the Creative Commons Attribution License, which permits unrestricted use, distribution, and reproduction in any medium, provided the original author and source are credited. 